\title{
PENGEMBANGAN PERANGKAT PEMBELAJARAN FISIKA BERBASIS PENDEKATAN KONSEP UNTUK MENINGKATKAN HASIL BELAJAR SISWA SMA
}

\author{
Mochammad Maulana Trianggono', Tjipto Prastowo², Soeparman Kardi ${ }^{3}$. \\ ${ }^{1}$ Mahasiswa program pascasarja pendidikan sains universitas negeri Surabaya \\ ${ }^{2,3}$, Dosen program pascasarja pendidikan sains universitas negeri Surabaya \\ Email: maulanafisika09@gmail.com
}

\begin{abstract}
The aim of this research is to develop physics learning material using concept approach learning-based to improve student achievement. This research was held using Dick and Carey design model and tested in X grade of SMAN 4 Jember usingone-group pretest-posttest design. Data were analyzed using descriptive analysis quantitatively and qualitatively. Validation results showed that learning material is feasible to be implemented, including: (a) lesson plan, (b) student worksheet, (c) student book, (d) assessment sheet. The results of this research were analyzed and obtained: lesson plan was properly implemented, good student responses, all students interested in learning. Knowledge aspect include concept understanding and creative thinking skills were analyzed by $\mathrm{N}$-gain showed high improvement. Conluded that, development of physics learning material based on concept approach is feasible to be implemented and it can improve the student achievement.
\end{abstract}

Keyword: Concept Approach.

\begin{abstract}
Abstrak Penelitianinibertujuanuntuk mengembangkan perangkat pembelajaran fisika menggunakan strategi pembelajaran berbasis pendekatan konsep untuk meningkatkan hasil belajar siswa. Penelitian ini dilaksanakan dengan menggunakan rancangan penelitian model Dick dan Carey dan diujicobakan di kelas X SMAN 4 Jember dengan desain ujicoba menggunaka none group pretest-posttest design. Analisis data dilakukan secara deskriptif kuantitatif dan kualitatif. Hasil validasi perangkat pembelajaran menunjukkan perangkat pembelajaran layak untuk diimplementasikan, meliputi: (a) RPP, (b) LKS, (c) Buku Siswa, (d) Instrumen Tes Hasil Belajar. Hasil penelitian ini dianalisis dan diperoleh beberapa temuan diantaranya: RPP terlaksana dengan baik, respon siswa sangat positif, semua siswa berminat dalam pembelajaran. Tes hasil belajar aspek pengetahuan yang meliputi pemahaman konsep dan kemampuan berpikir kreatif dianalisis dengan $\mathrm{N}$-Gain menunjukkan peningkatan yang tinggi. Berdasarkan hasil analisis dan pembahasan, disimpulkan bahwa perangkat pembelajaran yang dikembangkan layak digunakan dan dapat meningkatkan hasil belajar siswa.
\end{abstract}

Kata Kunci: Pendekatan Konsep.

\section{PENDAHULUAN}

Fisika merupakan ilmu pengetahuan yang mempelajari tentang alam dan gejalanya. Alam yang menjadi objek telaah fisika tersusun atas kumpulan benda-benda dan peristiwa-peristiwa yang saling terkait antara satu dan lainnya dengan sangat kompleks. Kompleksitas tersebut terangkum dalam berbagai fakta, teori, konsep, prinsip, dan hukum yang telah ditemukan oleh para ahli terdahulu. Dalam mempelajari fisika kita harus mampu mengaitkan fakta yang satu dengan fakta lainnya, mempelajari keterkaitan antar konsep serta keterkaitan lainnya. Menurut Arends (2012), konsep menjadi fondasi bagi jaringan (skemata) ide yang menuntun pemikiran kita. Belajar konsep lebih dari sekedar mengklasifikasikan berbagai objek dan membentuk berbagai kategori, namun belajar konsep juga melibatkan roses mengkonstruksikan pengetahuan dan mengorganisasikan informasi menjadi strukturstruktur yang komprehensif dan kompleks.

Proses pembelajaran yang ditekankan pada penerapan Kurikulum 2013 di sekolah adalah menggunakan pendekatan saintifik. Pendekatan saintifik menekankan pada bagaimana siswa memperoleh suatu konsep. Tujuan dari penggunaan pendekatan saintifik adalah agar siswa dapat menemukan teori dari suatu konsep melalui langkahlangkah yang dilakukan oleh ilmuwan dalam menemukan teori. Guru berperan sebagai fasilitator bagi siswa dalam proses inkuiri. Melalui pendekatan saintifik, siswa diajarkan untuk mengerti cara memperoleh konsep melalui suatu rancangan percobaan, namun belum tentu siswa tersebut mampu 
memahami konsep yang sedang mereka pelajari. Pendekatan saintifik menekankan pada proses inkuiri, yakni proses induktif untuk memperoleh teori dari generalisasi hasil penelitian yang dilakukan.

Berdasarkan wawancara awal dengan beberapa guru fisika di Jember, pemahaman konsep siswa dinilai kurang meskipun sudah menggunakan pendekatan saitifik. Siswa sering mengalami kesulitan dalam memahami konsep-konsep fisika. Kesulitan tersebut misalnya tampak dalam ketidakmampuan siswa dalam mengaitkan konsep-konsep fisika yang mereka pelajari. Pada proses pembelajaran, siswa memang melakukan percobaan untuk menemukan teori dari konsep tertentu, namun pada saat proses evaluasi, siswa cenderung belum memahami konsep yang telah mereka pelajari. Seringkali ditemukan miskonsepsi pada siswa tentang konsep-konsep fisika. Dalam taksonomi Bloom, pemahaman terhadap konsep adalah kemampuan kognitif tingkat 2 (C-2) sebelum penerapan dan tingkat yang lebih tinggi. Apabila pemahaman konsep siswa kurang, maka kemampuan kognitif pada tingkat yang lebih tinggi akan sulit dicapai oleh siswa. Pemahaman konsep juga mempengaruhi hasil belajar yang dicapai oleh siswa. Pemaham konsep yang rendah akan membuat hasil belajar siswa juga rendah.

Pemahaman terhadap konsep, prinsip, dan hukum fisika sangat dibutuhkan untuk mempelajari fisika. Diharapkan siswa mampu menyusun kembali dalam bahasanya sendiri sesuai dengan tingkat kematangan dan perkembangan intelektualnya. Pemahaman tersebut dapat dicapai oleh siswa melalui pendekatan konsep. Pendekatan konsep menekankan pada bagaimana siswa dapat memahami konsep melalui proses deduktif dan induktif. Menurut Arends (2012), proses pembelajaran yang digunakan dalam pendekatan konsep adalah proses deduktif melalui pembelajaran langsung dan penalaran induktif melalui pembelajaran inkuiri. Pembelajaran langsungadalah proses deduktif yang dilakukan dengan cara presentasi langsung yang menekankan pada pemberian label/ nama dan pendefinisian konsep, sedangkan Concept attaintment adalah proses penalaran induktif yang menekankan pada penemuan konsep melalui inkuiriBerdasarkan pendapat tersebut, pemahaman konsep akan lebih optimal dicapai menggunakan kedua proses dalam pendekatan konsep, yakni melalui proses deduktif dan proses induktif.Menurut Samparadja (2014), pendekatan induktif-deduktif dapat meningkatkan kemampuan siswa dalam membuktikan konsep. Kemampuan membuktikan membutuhkan pemahaman konsep yang baik. Berdasarkan temuan di atas, pembelajaran berbasis pendekatan konsep dapat digunakan untuk meningkatkan pemahaman konsep.
Pembelajaran dengan pendekatan konsep erat hubungannya dengan belajar bermakna yang dikemukakan oleh Ausubel. Menurut Novak (2011) dalam belajar bermakna, seseorang akan mengetahui bagaimana informasi baru terintegrasi dengan pengetahuan sebelumnya. Novak (2011) juga menemukan bahwa peta konsep dapat digunakan untuk mewakili pengetahuan yang dimiliki oleh siapa saja. Selain itu, dengan menggunakan peta konsep dapat membantu peserta didik belajar bagaimana belajar bermakna dan membantu para peneliti untuk mendesain dan menginterpretasikan penelitian dengan lebh efektif.

Menurut Arends (2012), peta konsep merupakan salah satu strategi organisasi yang bertujuan membantu pebelajar meningkatkan kebermaknaan bahan-bahan yang sedang dipelajarinya. Peta konsep adalah gambaran visual yang dapat dibangun oleh seseorang untuk membuat suatu informasi menjadi lebih bermakna, dan meningkatkan retensi sehingga dapat mengingatnya untuk jangka waktu lama. Penggunaan peta konsep dalam pembelajaran fisika sangat penting mengingat dalam mempelajari fisika siswa harus mampu mengaitkan keterkaitan antar konsep, prinsip, dan hukum-hukum fisika, sehingga dengan peta konsep diharapkan siswa mampu memetakan keterkaitan tersebut agar pemahaman siswa terhadap fisika meningkat. Maryanti (2012) menyatakan bahwa peta konsep dapat meningkatkan pemahaman siswa dalam pelajaran fisika.

Kurikulum 2013 didesain untuk memberikan pembelajaran yang menuntut siswa menggunakan caracara kreatif dalam pemecahan masalah. Kurikulum 2013 menekankan pendekatan saintifik dalam proses pembelajarannya, yang terdiri dari proses mengamati, menanya, mencoba, mengolah, menyajikan, menyimpulkan, dan mencipta untuk semua mata pelajaran (Kemendikbud, 2013). Pendekatan saintifik dirancang agar siswa mampu menggunakan seluruh kemampuannya untuk pemerolehan konsep, termasuk kemampuan berpikir tingkat tinggi. Kemampuan berpikir kreatif sangat dibutuhkan siswa untuk mengembangkan cara berpikirnya dalam pemerolehan konsep.

Berdasarkan hasil wawancara, kemampuan berpikir kreatif jarang dilatihkan kepada siswa, akibatnya siswa cenderung sulit untuk berpikir out of the box untuk memecahkan suatu permasalahan atau dalam pemerolehan konsep. Penggunaan peta konsep sebagai strategi pemerolehan konsep fisika juga diharapkan mampu melatihkan kemampuan berpikir kreatif siswa. Munandar (2009) mengungkapkan bahwa kreativitas adalah kemampuan untuk membuat kombinasikombinasi baru, atau melihat hubungan-hubungan baru antar unsur, data, atau hal-hal yang sudah ada 
sebelumnya. Kemampuan berpikir kreatif dapat diartikan sebagai kemampuan untuk berpikir orisinil yang bertujuan untuk memecahkan suatu persoalan dan mencetuskan ide-ide baru yang berbeda dengan lainnya. Kemampuan berpikir kreatif sangat dibutuhkan untuk memetakan konsep-konsep fisika sehingga menjadi suatu keterkaitan yang benar menurut teori dan mudah dipahami oleh siswa tersebut. Belajar dengan peta konsep juga sangat membantu melatihkan kemampuan berpikir kreatif siswa sehingga siswa memiliki kreativitas yang tinggi dalam memecahkan persoalan fisika.

Penggunaan peta konsep dalam pembelajaran fisika sudah diterapkan dengan baik, namun peta konsep hanya sebatas media visual yang diperlihatkan kepada siswa tanpa dimaknakan lebih dalam. Peta konsep hanya digunakan untuk brain storming pada saat awal pembelajaran, siswa tidak membuat sendiri peta konsep yang akan siswa pelajari. Siswa hanya menerima peta konsep yang diberikan oleh guru, sehingga kurang adanya kebermaknaan lebih lanjut dalam penggunaan peta konsep. Peta konsep yang diberikan juga hanya sebatas kumpulan konsep yang dihubungkan dengan kata hubung secara hirarkis dalam kotak atau lingkaran yang sangat sederhana dan disajikan pada papan tulis atau media power point. Peta konsep pada dasarnya merupakan strategi untuk belajar bermakna, sehingga seharusnya peta konsep tersebut juga harus lebih dimaknakan dan dilakukan oleh siswa sebagai pebelajar. Menurut Novak (2011), peta konsep yang dibuat oleh peserta didik berdasarkan pengetahuan yang dimiliki sebelumnya dapat memberikan informasi yang akurat tentang apa yang sudah diketahui oleh peserta, termasuk miskonsepsi mereka.

Tseng dkk. (2012) mengatakan bahwa pembelajaran dengan peta konsep dapat membantu siswa dalam transfer pengetahuan yang meliputi: 1) pemerolehan konsep, 2) komunikasi, 3) aplikasi, 4) penerimaan, 5) asimilasi. Berdasarkan pernyataan tersebut, pembelajaran dengan peta konsep dapat digunakan sebagai strategi untuk membantu siswa dalam pemahaman konsep. Siswa dapat mengklasifikasikan konsep dari yang umum hingga konsep yang lebih khusus.

Peta konsep harus disajikan dalam bentuk yang menarik dan mudah dipahami oleh siswa agar siswa mampu lebih kreatif dalam mengembangkan peta konsepnya sendiri. Peta konsep menjadi lebih bermakna apabila peta konsep tersebut mampu menyajikan pertanyaan yang dapat mewakili peta konsep itu sendiri dalam pemerolehan konsep. Konsep baru dalam penggunaan peta konsep dalam pembelajaran yakni mengkombinasikan peta konsep dengan peta pikiran yang ditunjang oleh penggunaan media presentasi Prezi sebagai media penyampaian interaktif yang menarik. Prezi merupakan perangkat lunak yang digunakan sebagai media presentasi berbasis internet yang berbentuk peta pikiran. Media presentasi prezi diharapkan dapat menunjang kualitas pembelajaran menggunakan perangkat peta konsep. Peta konsep menyajikan peta konsep yang membuat siswa berpikir lebih dalam untuk menyelesaikan persoalan yang disajikan dalam peta konsep. Penggunaan peta konsep dalam pembelajaran berbasis pendekatan konsep ini diharapkan mampu meningkatkan pemahaman dan kemampuan berpikir kreatif siswa dalam pembelajaran fisika.

Menurut Kao dkk. (2008), pemahaman konsep merupakan stimulus dari potensi kreatif yang dimiliki seseorang. Berdasarkan pendapat tersebut, pemahaman konsep yang baik dapat menjadi modal awal siswa untuk dapat meningkatkan kemampuan berpikir kreatifnya.Pemahaman konsep dan kemampuan berpikir kreatif siswa yang baik akan membuat hasil belajar siswa juga baik.

Berdasarkan uraian di atas, peneliti mengembangkan perangkat pembelajaran fisika berbasis pendekatan konsep untuk dapat meningkatkan kualitas pembelajaran fisika. Oleh karena itu, peneliti melakukan penelitian dengan judul "Pengembangan Perangkat Pembelajaran Fisika Berbasis Pendekatan Konsep Untuk Meningkatkan Hasil Belajar Siswa SMA".

\section{METODE PENELITIAN}

Penelitian ini bertujuan mengembangkan perangkat pembelajaran yang selanjutnya akan diimplementasikan di kelas sehingga penelitian ini dikategorikan sebagai penelitian pengembangan (development research). Perangkat pembelajaran yang dikembangkan meliputi: rencana pelaksanaan pembelajaran (RPP), buku siswa, lembar kerja siswa (LKS), instrumen penilaian hasil belajar. Rancangan penelitian yang digunakan dalam penelitian menggunakan model Dick dan Carey.

Penelitian ini dilakukan melalui dua tahapan, yaitu tahap pengembangan perangkat pembelajaran dan tahap uji coba. Ujicoba ini dilaksanakan di SMAN 4 Jember kelas X IPA 2, X IPA 3, dan X IPS 2.. Rancangan dalam Ujicoba ini menggunakan desain one-group pretest-posttest design.

Model pengembangan perangkat pengembangan yang digunakan dalam penelitian ini adalah model Dick dan Carey yang diadaptasi dari Dick, Carey, \& Carey (2009) seperti yang ditunjukkan pada Gambar 1. 


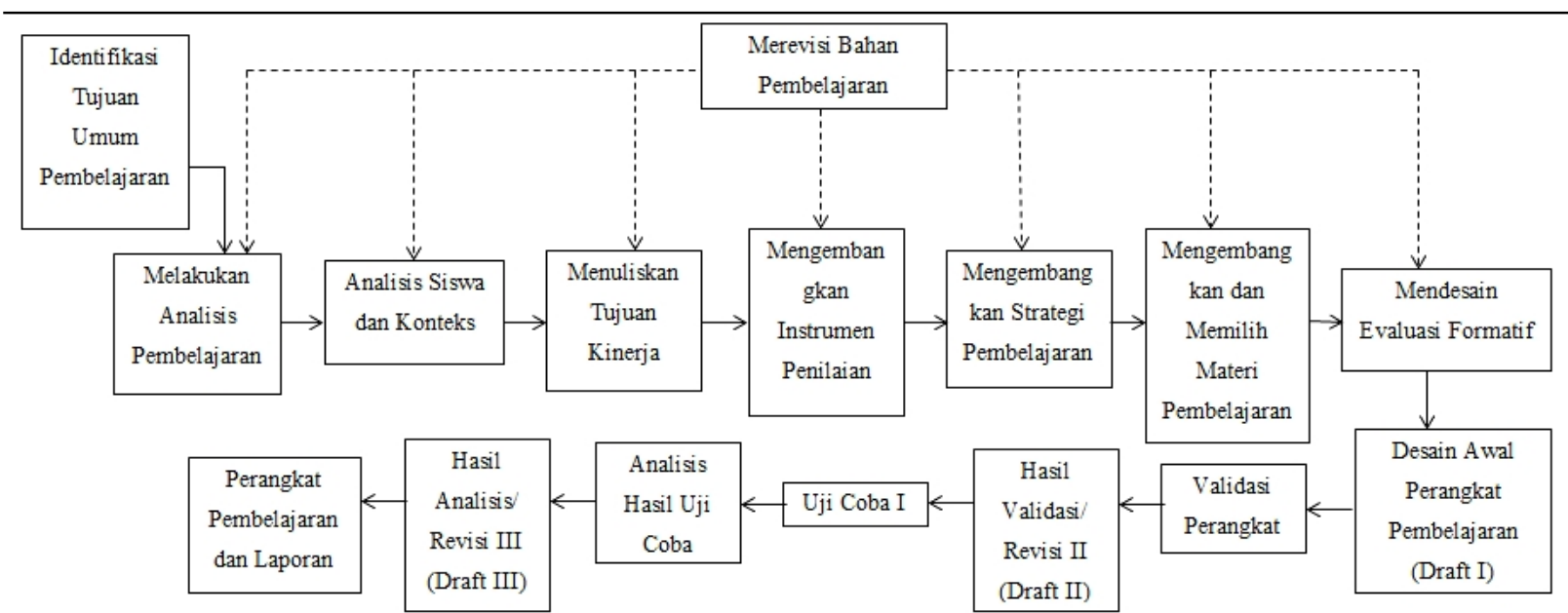

Gambar 1. Prosedur Pengembangan Perangkat Pembelajaran (diadaptasi dari Dick, Carey, dan Carey, 2009)

Pengumpulan data yang dilakukan dalam penelitian ini menggunakan teknik observasi, tes, dan angket. Untuk mendapatkan data yang akurat dalam penelitian,maka terdapat instrumen-instrumen penelitian yang digunakan diantaranya (1) lembar validitas perangkat pembelajaran yang meliputi RPP, buku siswa, LKS, dan penilaian hasil belajar,(2) lembar keterlaksanaan pembelajaran, (3) Tes hasil belajar siswa yang meliputi tes pemahaman konsep dan kemampuan berpikir kreatif, (4) angket respon siswa, dan (5) lembar pengamatan kendala selama proses pembelajaran.

Teknik Analisis data dilakukan secara deskriptif kuantitatif dan kualitatif. Data mengenai validitas atau kelayakan perangkat pembelajaran yang dikembangkan dikumpulkan dengan teknik validasi dengan menggunakan lembar validasi perangkat pembelajaran. Validator memberikan penilaiannya terhadap perangkat pembelajaran yang dikembangkan pada lembar validasi perangkat pembelajaran.Kategori validasi perangkat pembelajaran disajikan dalam Tabel 1.

Tabel 1. Kategori validasi perangkat pembelajaran

\begin{tabular}{|c|c|l|}
\hline Interval Skor rata-rata & Kategori & \multicolumn{1}{|c|}{ Keterangan } \\
\hline $1,0 \leq \mathrm{SV} \leq 1,59$ & Tidak Baik & $\begin{array}{l}\text { Belum dapat digunakan dan masih } \\
\text { memerlukan konsultasi }\end{array}$ \\
\hline $1,60 \leq \mathrm{SV} \leq 2,59$ & Kurang Baik & Dapat digunakan dengan banyak revisi \\
\hline $2,60 \leq \mathrm{SV} \leq 3,59$ & Baik & Dapat digunakan dengan sedikit revisi \\
\hline $3,60 \leq \mathrm{SV} \leq 4,00$ & Sangat Baik & Dapat digunakan tanpa revisi \\
\hline
\end{tabular}

Sumber: Ratumanan dan Laurens (2011)

Analisis data hasil belajar dilakukan secara deskriptif kuantitatif dan kualitatif yang meliputi hasil belajar aspek pengetahuan, pemahaman konsep dan kemampuan berpikir kreatif dengan perhitungan sebagai berikut.

Presentase Skor Perolehan $(S P)=\frac{\text { Jumlah } \text { skor }}{\text { Skor maksimal }} \times 100 \%$

Selanjutnya, data hasil pretest dan posttest kemampuan proses dan psikomotor dilakukan analisis deskriptif kualitatif yaitu analisis $N$-Gain yang dirumuskan oleh Hake (1999).

$$
\langle g\rangle=\frac{\left\langle S_{\text {post }}\right\rangle-\left\langle S_{\text {pre }}\right\rangle}{100 \%-\left\langle S_{\text {pre }}\right\rangle}
$$

Nilai gain menunjukkan peningkatan hasil belajar siswa sebelum dan setelah diberikan perlakuan. Peningkatan pemahaman konsep dan kemampuan berpikir kreatif juga dianalisis dengan menggunakan analisis $N$-Gain. Kriteria perolehan skor gain ternormalisasi menurut Hake (1999) diklasifikasikan ke dalam tiga tingkatan seperti pada Tabel 2 .

Tabel 2. Klasifikasi peningkatan skor

\begin{tabular}{|c|c|}
\hline Koefisien Normalisasi gain & Klasifikasi \\
\hline $\mathrm{g}<0,3$ & Rendah \\
\hline $0,3 \leq \mathrm{g}<0,7$ & Sedang \\
\hline $\mathrm{g} \geq 0,7$ & Tinggi \\
\hline
\end{tabular}

Penilaian kemampuan berpikir kreatif siswa diperoleh dari tes kemampuan berpikir kreatif. Masingmasing item tes dinilai dengan metode penskoran berdasarkan indikator yang telah ditetapkan yang meliputi kelancaran (fluency), kelenturan (flexibility), orisinalitas (originallity), dan elaborasi (ellaboration). Kriteria kemampuan berpikir kreatif siswa disajikan pada Tabel 3.

Tabel 3. Kriteria Kemampuan Berpikir Kreatif

\begin{tabular}{|c|c|}
\hline Nilai (\%) & Kriteria \\
\hline $81,6 \%-100 \%$ & sangat kreatif \\
\hline $61,2 \%-81,5 \%$ & kreatif \\
\hline $40,8 \%-61,1 \%$ & Cukup kreatif \\
\hline $20,4 \%-40,7 \%$ & Kurang kreatif \\
\hline $0,0 \%-20,3 \%$ & Tidak kreatif \\
\hline
\end{tabular}
sumber: Khanafiyah, 2010

Respon siswa diperoleh dari angket respon siswa. Respon siswa dianalisis secara deskriptif dengan presentasi menggunakan rumus perhitungan respon siswa sebagai berikut. 


$$
\mathrm{P}=\frac{\Sigma K}{\Sigma N} \mathrm{X} 100 \%
$$

Kendala selama pelaksanaan kegiatan belajar mengajar dianalisis dengan deskriptif kualitatif yaitu pengamat dan peneliti memberikan memberikan catatan hambatan-hambatan yang terjadi pada pelaksanaan pembelajaran sebanyak dua pertemuan disertai dengan saran dari pengamat.

\section{HASIL DAN PEMBAHASAN}

\section{A. Kelayakan Perangkat Pembelajaran}

Perangkat pembelajaran yang divalidasi terdiri atas RPP, buku siswa, LKS, tes hasil belajar. Telaah validasi yang dilakukan terhadap isi perangkat pembelajaran bertujuan untuk mendapatkan saran yang akan digunakan untuk acuan dalam merevisi perangkat yang akan dikembangkan. Berdasarkan hasil validasi oleh ahli pendidikan tersebut, peneliti selanjutnya menerapkan perangkat yang telah divalidasi tersebut untuk pengambilan data.

Berdasarkan data hasil validasi RPP, Buku Siswa, LKS, dan tes hasil belajar, diperoleh bahwa (1) RPP mendapatkan rata-rata skor 3,72 dengan kategori sangat valid artinya RPP yang dikembangkan dapat digunakan pada pembelajaran; (2) LKS mendapatkan rata-rata skor 3,67 dengan kategori sangat valid artinya LKS tersebut dapat digunakan dalam proses pembelajaran; (3) Buku siswa mendapatkan rata-rata skor 3,55 dengan kategori valid artinya buku siswa yang dikembangkan dapat digunakan dalam proses pembelajaran; (4) Tes hasil belajar yang disusun memiliki kategori sangat valid namun memiliki reliabilitas yang sedang. Soal ini dapat digunakan dengan revisi sehingga layak digunakan dalam proses pembelajaran.

\section{B. Keterlaksanaan Perangkat Pembelajaran}

Secara umum keterlaksanaan RPP memiliki skor rata-rata 3,85 yang memiliki kategori sangat baik. Hal ini menunjukkan bahwa dalam pelaksanaan pembelajaran fisika dengan menggunakan perangkat pembelajaran berbasis pendekatan konsep dapat dikategorikan sangat baik. Diagram keterlaksanaan RPP disajikan pada Gambar 2.

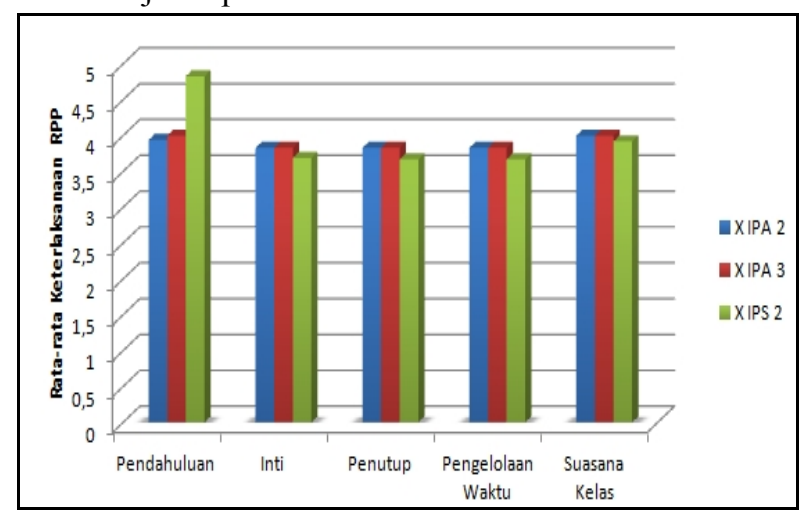

Gambar 2. Diagram Keterlaksanaan RPP
Pendahuluan yang dilakukan oleh guru meliputi penyampaian apersepsi dan motivasi, penyampaian tujuan dan melakukan advance organizer dengan peta konsep telah terlaksana dengan sangat baik. Kegiatan inti yang merupakan pokok dari pembelajaran berbasis pendekatan konsep yang meliputi proses deduktif dan induktif telah terlaksana dengan baik.

Tahap penutup pada ketiga kelas memperoleh skor rata-rata sangat baik. Pemberian evaluasi berupa soalsoal berpikir kreatif membuat siswa antusias dalam mengerjakan dan mengajukan pertanyaan yang terkait dengan konsep dan berpikir kreatif. Guru dapat mengelola waktu dengan sangat baik. Siswa dapat mengikuti prosedur pembelajaran dengan lancar dan tepat waktu, sehingga waktu yang diperlukan untuk melakukan setiap tahapan pembelajaran juga dapat lebih efisien. Siswa dan guru tampak antusias dalam pelaksanaan pembelajaran.

Pada pembelajaran pertama di kelas X IPS 2, siswa masih terlihat ramai dan kurang memperhatikan guru di depan. Hal ini diakibatkan karena siswa X IPS 2 kurang meminati pelajaran fisika. Solusi yang dilakukan oleh guru adalah membuat agar pembelajaran menjadi lebih nyaman dan menyenangkan dengan cara memberikan pendekatan santai kepada siswa dan memberikan ilustrasi-ilustrasi yang menarik tentang konsep yang akan diberikan. Guru dapat membuat suasana ruang kelas menjadi lebih nyaman dan menyenangkan, sehingga dapat membuat siswa antusias dalam mengikuti pembelajaran.

Berdasarkan Gambar 2, secara umum pembelajaran telah terlaksana dengan sangat baik. Keterlaksanaan pembelajaran di ketiga kelas menunjukkan grafik yang seimbang, hal ini berarti guru telah mengikuti tahapantahapan pembelajaran pada RPP dengan sangat baik dan konsisten.

\section{Kefektifan Perangkat Pembelajaran}

1. Hasil Belajar Siswa pada Pembelajaran Fisika Berbasis Pendekatan Konsep

Menurut Kardi (2012), hasil belajar adalah indikator yang komprehensif, dapat diamati dan diukur, tentang keberhasilan siswa pada tahap pembelajaran tertentu. Hasil belajar siswa diukur dengan melakukan tes hasil belajar. Tes hasil belajar diberikan pada saat pre test dan post test. Tes hasil belajar terdiri dari 12 soal pilihan ganda dan 10 soal uraian yang diantaranya termasuk soal berpikir kreatif dan soal pemahaman konsep.

Konsep suhu dan kalor adalah materi awal yang diberikan di kelas X meskipun sebelumnya juga pernah diberikan pada saat SMP, sehingga siswa masih kesulitan dalam mengingat materi tersebut untuk menjawab pertanyaan-pertanyaan yang diberikan dalam pre test. Sebelum diberikan pembelajaran berbasis 
pendekatan konsep, siswa memang belum pernah diberikan latihan soal-soal berpikir kreatif, sehingga pada saat diberikan soal berpikir kreatif, siswa masih bingung dalam menjawab pertanyaan yang diberikan. Pembelajaran berbasis pendekatan konsep yang diterapkan dapat membantu siswa dalam memahami konsep dan melatihkan kemampuan berpikir kreatif, sehingga pada saat mengerjakan post test, siswa dapat dengan lancar menjawab pertanyaan yang diberikan.Peningkatan hasil belajar siswa setelah mengikuti pembelajaran berbasis pendekatan konsep disajikan pada Gambar 3.

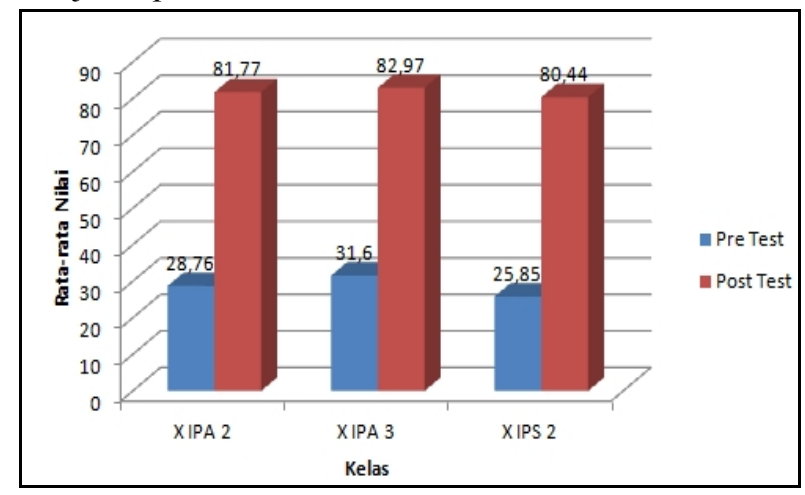

Gambar 3. Diagram Peningkatan Hasil Belajar Siswa

Berdasarkan Gambar 3, ketiga kelas menunjukkan peningkatan dengan kategori tinggi (nilai peningkatan masing-masing kelas sebesar 0,$74 ; 0,75$; dan 0,74). Hal ini menunjukkan bahwa pembelajaran berbasis pendekatan konsep efektif digunakan untuk meningkatkan hasil belajar fisika siswa. Peningkatan hasil belajar siswa ini juga didukung oleh latihan soal yang ada pada buku siswa, tes formatif secara berkala pada setiap akhir pembelajaran, dan tugas membuat peta konsep. Siswa juga tertantang untuk mengerjakan soal-soal kreatif, sehingga semakin terlatih dalam mengembangkan kemampuan berpikir kreatif siswa yang berdampak pada meningkatnya hasil belajar.

Pemahaman konsep yang baik dan kemampuan berpikir kreatif yang tinggi menunjang peningkatan hasil belajar siswa. Peta konsep yang digunakan dalam pembelajaran berbasis pendekatan konsep sangat membantu dalam proses pemerolehan konsep dan berpikir kreatif. Arends (2012) berpendapat bahwa peta konsep merupakan salah satu strategi organisasi yang bertujuan membantu pebelajar meningkatkan kebermaknaan bahan-bahan yang sedang dipelajarinya. Pemahaman konsep yang baik akan mendukung perkembangan kemampuan berpikir kreatif siswa. Meningkatnya pemahaman konsep dan kemampuan berpikir kreatif berbanding lurus dengan meningkatnya hasil belajar siswa. Berdasarkan uraian tentang hasil belajar siswa tersebut dapat disimpulkan bahwa pembelajaran berbasis pendekatan konsep dapat meningkatkan hasil belajar siswa.
2. Pemahaman Konsep Siswa pada Pembelajaran Fisika Berbasis Pendekatan Konsep

Pemahaman konsep menurut Van de Walle (2008) dapat didefinisikan sebagai ukuran kualitas dan kuantitas hubungan suatu ide dengan ide yang telah ada. Berdasarkan definisi tersebut, pemahaman konsep dapat ditingkatkan melalui pembelajaran dengan peta konsep. Pemahaman konsep siswa diukur menggunakan tes pemahaman konsep yang tercakup dalam soal-soal pre test dan post test. Soal-soal pemahaman konsep mengacu pada indikator pemahaman konsep. Menurut Anderson dan Krathwohl (2001) terdapat 7 indikator pemahaman konsep, yakni interpreting, exemplifying, classifying, summarizing, inferring, comparing, explaining. Peningkatan pemahaman konsep setelah mengikuti pembelajaran berbasis pendekatan konsep disajikan pada Gambar 4.

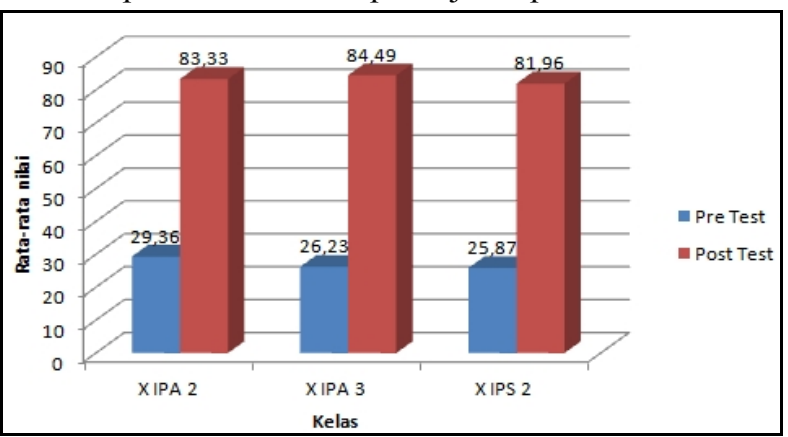

Gambar 4. Diagram Peningkatan Pemahaman Konsep Siswa

Berdasarkan Gambar 4, Ketiga kelas menunjukkan peningkatan dengan kategori tinggi (nilai peningkatan masing-masing kelas sebesar 0,76; 0,79; dan 0,76). Hal ini menunjukkan bahwa pembelajaran berbasis pendekatan konsep efektif digunakan untuk meningkatkan pemahaman konsep siswa siswa. Pemahaman konsep merupakan tahapan dasar kemampuan berpikir seseorang. Pemahaman konsep yang baik diharapkan mampu menjadi modal awal seseorang untuk meningkatkan kemampuan berpikir tingkat tingginya

3. Kemampuan Berpikir Kreatif Siswa pada Pembelajaran Fisika Berbasis Pendekatan Konsep

Menurut Johnson (2010) berpikir kreatif adalah sebuah kebiasaan dari pikiran yang dilatih dengan memperhatikan intuisi, menghidupkan imajinasi, mengungkapkan kemungkinan-kemungkinan baru, membuka sudut pandang yang menakjubkan, dan membangkitkan ide-ide yang tidak terduga. Berdasarkan pendapat tersebut kemampuan berpikir kreatif perlu dilatihkan agar siswa mampu menggunakan kemampuan kreatifnya untuk menyelesaikan suatu permasalahan dengan banyak kemungkinan penyelesaian. Kemampuan berpikir kreatif siswa diukur dengan melakukan tes kreativitas. 
Soal-soal berpikir kreatif terdapat dalam soal pre test dan post test. Soal berpikir kreatif berjumlah 9 soal uraian. Setiap soal mengandung keempat indikator kemampuan berpikir kreatif yang diukur (fluency, flexibility, originality, dan elaboration). Peningkatan kemampuan berpikir kreatif siswasetelah mengikuti pembelajaran berbasis pendekatan konsep disajikan pada Gambar 5.

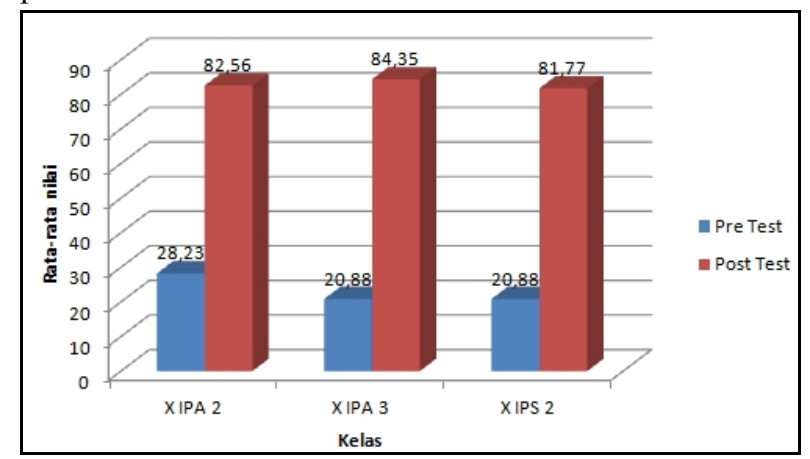

Gambar 5. Diagram Peningkatan Kemampuan Berpikir Kreatif Siswa

Gambar 5 menunjukkan bahwa kemampuan berpiki kreatif siswa pada kelas X IPA 2, X IPA 3, dan X IPS 2 mengalami peningkatan. Peningkatan n-gainyang diperoleh ketiga kelas tersebut berturut-urut adalah sebesar 0,$76 ; 0,80$; dan 0,76 serta memiliki kategori peningkatan tinggi. Peningkatan kemampuan berpikir kreatif siswa ditunjukkan dengan semakin lancarnya siswa dalam menuliskan gagasan dan contoh yang benar, meningkatnya kemampuan siswa dalam mencetuskan ide berdasarkan sudut pandang yang berbeda-beda, memberikan gagasan unik, dan membuat detail-detail secara rinci. Hasil tersebut sejalan dengan pendapat Kao (2008), bahwa penggunaan peta konsep dapat meningkatkan potensi kreatif dan tingkat penguasaan konsep seseorang. Peta konsep digunakan sebagai strategi penyampaian konsep dalam pembelajaran berbasis pendekatan konsep.

Secara umum, baik pemahaman konsep maupun kemampuan berpikir kreatif memiliki peningkatan yang tinggi. Hal ini sesuai dengan pendapat Susanto (2011) yang mengatakan bahwa pemahaman terhadap suatu konsep dalam pemecahan masalah akan dapat menimbulkan pola pikir kreatif pada siswa. Berdasarkan uraian tersebut, dapat dibuat suatu hubungan antara pemahaman konsep dengan kemampuan berpikir kreatif. Pemahaman konsep yang baik akan dapat membantu siswa dalam berpikir kreatif, sedangkan siswa yang memiliki kemampuan berpikir kreatif yang tinggi dapat menggunakan upaya kreatif dalam memahami suatu konsep. Berdasarkan temuan di atas dapat dikatakan bahwa pemahaman konsep dan kemampuan berpikir kreatif memiliki hubungan positif atau saling menguatkan.
4. Respons Siswa selama Pembelajaran Fisika Berbasis Pendekatan Konsep

Respons siswa adalah tanggapan yang diberikan siswa setelah mengikuti pembelajaran. Respon siswa diukur menggunakan instrumen angket respons siswa. Siswa diminta untuk mengisi angket yang berisi pendapat dan penilaian terhadap pelaksanaan pembelajaran dan komponen pendukungnya yang meliputi; ketertarikan terhadap komponen pembelajaran, kebaruan komponen pembelajaran, kesulitan dalam pembelajaran, dan metode pembelajaran yang diterapkan.

Kelas X IPA 2 memberikan respons positif sebesar 92,29\%, kelas X IPA 3 memberikan respons positif sebesar 90,63\%, dan kelas X IPS 2 memberikan respons positif sebesar $93,51 \%$. Secara keseluruhan pembelajaran yang telah dilaksanakan di kelas X IPA 2, X IPA 3, X IPS 2 memperoleh tanggapan/respon sangat positif. Hal ini berarti siswa senang dan antusias dalam mengikuti pembelajaran fisika berbasis pendekatan konsep yang diberikan.

Siswa kelas X IPS 2 pada dasarnya kurang menyukai pelajaran fisika, jadi pada saat pembelajaran pertama, siswa banyak yang masih ramai dan kurang memperhatikan guru mengajar. Solusi yang dilakukan guru adalah memberikan pendekatan dengan cara memberikan humor dan pembelajaran yang sedikit santai, serta memberikan ilustrasi-ilustrasi menarik terkait dengan konsep yang akan diajarkan.

\section{KESIMPULAN}

\section{A. Simpulan}

Berdasarkan temuan-temuan dan pembahasan, diperoleh kesimpulan bahwa perangkat pembelajaran berbasis pendekatan konsep yang telah dikembangkan bersifat valid dan layak digunakan untuk meningkatkan hasil belajar siswa SMA.

\section{B. Saran}

Berdasarkan penelitian yang telah dilakukan dan hasil yang didapat, disarankan beberapa hal sebagai berikut:

1. Guru harus cermat dalam mengatur alokasi waktu yang dibutuhkan pada setiap tahap dalam pembelajaran;

2. Pada pembelajaran perlu diberitahukan perkembangan kemampuan berpikir kreatif kepada siswa agar siswa semakin termotivasi untuk meningkatkan kemampuan berpikir kreatif mereka.

\section{DAFTAR PUSTAKA}

Arends, R. I. (2012). Learning to Teach: Ninth Edition. USA: The McGraw-Hill Companies 
Dick, W., Carey, L., \& Carey, J. O. (2009). The Systematic Design of Instruction 7th ed. New Jersey: Pearson Education

Johnson, S. (2010). Where Good Ideas Come From. New York: Riverhead books

Kao, G. Y.-M., Lin, S. S. J., \& Sun, C.-T. (2008). Breaking Concept Boundaries to Enhance Creative Potential: Using Integrated Concept Maps for Conceptual Self-Awareness. Elsevier: Computer \& Education 51, 1718-1728

Kardi, S. (2012). Pengantar Pengembangan Kurikulum dan Rencana Pelaksanaan Pembelajaran. Surabaya: Universitas Negeri Surabaya

Kemendikbud. (2013). Permendikbud No. 64 Tahun 2013 tentang Standar Isi. Jakarta: Kemendikbud

Khanafiyah, S \& Rusilowati, A. (2010). Penerapan pendekatan modified free inquiry sebagai upaya meningkatkan kreativitas mahasiswa calon guru dalam mengembangkan jeensi eksperimen dan pemahaman terhadap materi fisika. Jurnal Pendidikan FMIPA Universitas Negeri Semarang.

Krathwohl, D. R. \& Anderson, L. W. (2001). A Taxonomy for Learning, Teaching, and Assessing: A Revision of Bloom's Taxonomy of Educational Obejctives. New York: Longman

Maryanti, S., Fatmaryanti, S. D., \& Kurniawan, E. S. (2012). Peningkatan Pemahaman Siswa Dengan Penerapan Peta Konsep Pada Mata Pelajaran Fisika Kelas X SMK Muhammadiyah Kroya. Jurnal Radiasi No. 1, Vol. 1

Munandar, Utami (2009). Pengembangan Kreativitas Anak Berbakat. Jakarta: Rineka Cipta
Novak, J. D. (2011). A Theory of Education: Meaningful Learning Underlies The Constructive Integration of Thinking, Feeling, and Acting Leading to Empowerment for Commitment and Responsibility. Aprezindagem Significativa em Revista/ Meaningful Learning Review - V1(2), pp. 1-14

Ratumanan, TG dan Laurens, T. (2011). Evaluasi hasil belajar yang relevan dengan kurikulum berbasis kompetensi. Surabaya: Unesa University Press.

Samparadja, H., Wahyudin, Suryadi, D., \& Kartasasmita, B. G. (2014). The Influence of Inductive-Deductive Approach Based on Modified Definition in Algebra Structure Learning Toward Student's Proving Ability Viewed Based on College Entrance Track. International Journal of Education and ResearchVol. 2, no. 7, pp. 239-248

Susanto, H. A. (2011). Pemahaman Pemecahan Masalah Pembuktian Sebagai Sarana Berpikir Kreatif. Prosiding Seminar Nasional Penelitian, Pendidikan, dan Penerapan MIPA, Fakultas MIPA, Universitas Negeri Yogyakarta, 189-196

Tseng, K.-H., Chang, C.-C., Lou, S.-J., Tan, Y., \& Chiu, C.-J. (2012). How Concept-mapping Perception Navigates Student Knowledge Transfer Performance. Educational Technology \& Society, 15(1), 102-115

Van de Walle, J. A. (2008). Matematika Sekolah Dasar dan Menengah. Jakarta: Erlangga 